\title{
THE INFLUENCE OF FOOD SYMBOLISM ON FOOD INSECURITY IN SOUTH AFRICA: HOW RELEVANT IS THE EUCHARISTIC CELEBRATION?
}

\author{
George Byarugaba \\ University of the Western Cape
}

\begin{abstract}
Various research results point out poverty, inadequate food production and inadequate distribution as the main culprits for food insecurity in many African countries. This article wishes to contribute to the existing knowledge on food insecurity and concentrate on South Africa and investigate whether food symbolism can also lead to systematic food insecurity and discrimination of some people. Since the official end of political apartheid in 1994, there have been great improvements in terms of grants, aid, increase in food production and change of structures. Nevertheless, food insecurity still persists. This research seeks to uncover new facts concerning the cause for food insecurity in South Africa. It brings to the fore that instead of focusing on structural changes only, researchers need to re-evaluate some of the cultural and religious beliefs attached to food production, distribution and consumption. The article also hopes to highlight that the Eucharist which is a centre of Christian life ought to unite the faith-based communities and confront the vice of injustice in all its forms which exacerbates the problem of food insecurity. Christian encounter with Christ through the Eucharist forms the believers into a community of brothers and sisters and empowers people to participate in the liberating mission of the Lord. This solution would go to the roots of the moral problem of food insecurity and put institutions and structures on a new, more humane and beneficial foundation.
\end{abstract}

Key Words: Food Insecurity; Contestations; Symbolism; Eucharist

\section{Introduction}

Since the inception of a democratically elected government in 1994, South Africa has registered many successes in terms of governance, the rule of law, and social service provision among others. Nevertheless, food insecurity remains one of the greatest challenges. According to the study carried out by the National Food Consumption Survey in children aged 1-9 year, in South Africa $10.3 \%$ of the children is underweight and $21.6 \%$ of the children are stunted (Vermeer \& Tempelman, 2006:91). This implies that despite the fact that the international community ${ }^{1}$ has frequently reaffirmed the right to adequate food as a

The principal instruments establishing human rights in international law are: The Universal Declaration of Human Rights 1948 par. 25; the Declaration of the Rights of the Child 1959 principles 4 and 8; the International Covenant on Economic, Social and Cultural Rights 1996 art. 11.1, 2; the Universal Declaration on the Eradication of Hunger and Malnutrition 1974; the Rome Declaration on World Food Security 1996 art. 1; and the Plan of Action of the World Food Summit 1996 objective 7.4. 
serious matter, a disturbing gap still exists between the standards set and the situation prevailing in many parts of world (Brand \& Russell, 2002:77).

The experience of food insecurity in South Africa is so harsh that many South Africans now question the kind of democracy that the government of African National Congress (ANC) instituted after its successful fight against apartheid. As hard as it may be to believe, in a rich country like South Africa there are many South Africans who sleep on empty stomachs, children who suffer malnutrition or die from malnutrition related diseases, and women who prostitute themselves or exchange sex for food as a survival strategy.

It is not surprising then that some South Africans, especially those who lack food, shelter, and medical care question the meaning of democracy. For them, the democratic rights of voting and participatory governance that began at the end of apartheid rule and the development of the economy cannot have much significance unless these are accompanied by the provision of food and other basic necessities of life. Consequently, it is not unusual to hear such remarks as: "Is this the kind of democracy that we fought for?" In other words, when people compare the rate of unemployment, poverty, and food insecurity, they regrettably say that the apartheid government was much better.

Looking back, it seems inconceivable to imagine that such comments come from people who were seeking the basic aspects of human dignity: the right to vote, freedom to eat in restaurants of their choice and move freely along the beaches (Marsh \& Perkins 2009:10). The fact is that their dreams and expectations of "A better life for all" as promised by the ANC government are unfulfilled. As South African theologian Albert Nolan succinctly points out:

In South Africa an enormous amount of hope was generated by the struggle itself and by its success in dismantling apartheid, by the negotiated settlement, by the relatively peaceful transition to democracy, by our new constitution, and by the charismatic leadership of Mandela. But since then our hopes have been gradually eroded, and today the general mood can only be described as disillusionment and despair (2010:5).

What Nolan is saying is that the problem of food insecurity, among others, makes political democracy meaningless. No matter how often South African are allowed to go to the ballot box, if nothing is done to deracinate food insecurity, there cannot be true democracy (Moore Lappé et al., 1978:273). In other words, the political democracy is undercut by famine and widespread hunger, the violation of basic liberties, corruption, extensive neglect of the interests of and rights of women, as well as worsening harm to the environment and to the sustainability of economic and social lives (Sen 2000:xi). The current article argues that one of the causes of food insecurity is food contestation resulting from the various symbols attached to food. Focusing on the religious communities the article suggests that if the problem of food insecurity is to be addressed comprehensively, the religious communities following in the footstep of Jesus Christ who came to give people abundance life, must work together with the local communities and the government to address the problem.

\section{The Meaning of Food Insecurity}

Food insecurity is defined as lack of secure access by households and individuals to nutritionally adequate food at all times and procured in conformity with human aspirations and dignity (Awetori 2004:23-37). This definition usually includes food supply, access, adequacy, utilisation, safety and cultural acceptability of food for all people at all times (Crush et al. 2007:23). In the South African context, The Integrated Food Security Strategy for South Africa defines food insecurity as lack of accessibility to the physically, socially 
and economically sufficient, safe and nutritious food by all South Africans at all times to meet their dietary and food preferences for an active and healthy life. ${ }^{2}$ According to Jonathan Crush et al. (2007:23), a population or livelihood group is considered acutely 'food insecure' when:

- people experience a large reduction in their major source of food and are unable to make up the difference through new strategies;

- the prevalence of malnutrition is abnormally high for the time of year, and this cannot be accounted for by either health or care factors;

- a large proportion of the population or group is using marginal or unsustainable coping strategies; and

- people are using 'coping' strategies that are damaging their livelihoods in the longer term, or incurring some other unacceptable cost, such as acting illegally or immorally (Crush et al., 2007:23).

\section{Causes of Food Insecurity in South Africa}

Various research results point out many factors as the major culprits of food insecurity in South Africa. These include inadequate food production and distribution; poverty, natural disasters-drought, floods, and other events beyond human control-; over-population, laziness and poor storage. This narrow way of framing the causes of food insecurity is likely to treat it as a naturally-induced phenomenon. It can as well easily place the blame on the victims as well as creating a perception among many people, including the victims of food insecurity, to look at it as a 'given,' as part of the social order so much so that instead of demanding its eradication as a moral issue they only react against acute hunger (Häring, 1985:307). The truth is that the problem of food insecurity is not an inevitable reality, nor unavoidable in any fatalistic sense of the term. If everybody including those who are affected really viewed food insecurity as a moral problem entailing our obligation to assist the vulnerable as not a unique positive responsibility, but rather a general moral duty that ungirds all special role responsibilities, we would do what it takes to assist those who are vulnerable as well as finding ways of stopping it (Frey \& Wellman, 2008:239).

Without disregarding the above causal factors, this article argues that food symbolism has a significant influence on food production, distribution and consumption. In other words, the symbols attached to foodstuffs lead to food contestation, which in turn leads to food insecurity. This kind of cause perpetuates food insecurity in times of both famine and plenty. Consequently, if focusing on socio-economic structures such as food production and distribution as the only major causes of food contestation and food insecurity the proposed solutions are likely to be purely technological. Now let us first look at food contestation.

\section{Food Contestation}

The word contestation is somehow connected to contest. They are linked both through meaning and through etymology. Both words can be traced to the Latin verb contestari, meaning, to call to witness. Contest can be a verb meaning, 'to dispute.' Contestation essentially means 'an act,' 'instance,' or 'state of contesting 'or 'an event' in which people compete in sport or other activity. In this regard, food contestation implies a state, an act, or instance in which people compete for food.

Integrated Food Security Strategy for South Africa: "This definition has four distinct but inter-related components: food availability, food access or effective demand, reliability, and food distribution." Available from http//www. nda.agric.za/doaDev, Internet; Accessed; March 11, 12. 
Food contestation is not a new experience in the history of humankind. As Wylie (2001:29) reports, "Letting the weak die" during the times of famine to allow the stronger to survive has always been used as a method of coping during times of hunger. Wylie further indicates that families in both Europe and Africa sometimes had to fragment by jettisoning hungry dependents. Alcock (2008:9) concurs with Wylie that during World War I, food was rationed in Britain so much that a Ministry of Food was created to implement the exercise. Its role was to ensure the smooth running of the programme as well as maintaining a fair share that was morally acceptable to the public and provided a reasonnably nutritious diet. In an African context and South Africa in particular, food contestation is a common practice. While food rationing/contestation is sometimes required in order to ensure the equal sharing as we have seen, the contestation that comes as a result of food symbolism leads to food insecurity, as we shall soon see. Moreover, the longevity of food insecurity in human history does not justify its practice especially in this age of improved science and technology.

\section{The Meaning of Symbolism}

Fiddes (1991:41) defines the term symbolism as communication that is distinct from direct, literal, discourse. According to this definition, oral expressions, gestures, rituals, objects, or actions are symbolic when they represent something beyond their obvious identities. Systematic use of symbols is a dominant feature of most societies without written language (Éla, 2009:35). For example, a flag is symbolic because it is more than a piece of decorative cloth. Food is symbolic too. The kola nut in some West African countries is a good example of food symbolism. According to Jean-Marc Éla (2009:35), the richness of meaning of the kola nut represents all wisdom. No assembly or wedding can take place without it. Besides kola nut, millet, bananas, yam and milk are "traditionally essential items" in many African communities.

Besides being only one of the aspects of human livelihood, food is probably one of the most resonating cultural items and it means much more than nutrition. As Lupton succinctly points out:

There are manifold cultural meanings and discourse surrounding food practices and preferences in all human societies. Indeed, food is the symbolic medium par excellence. Food consumption habits are not simply tied to biological needs but serve as mark boundaries between social classes, geographic regions, nations, cultures, genders, lifecycle stages, religions and occupations, to distinguish rituals, traditions, festivals, seasons and times of the day. Food 'structure[s] what counts as a person in culture' (1996:1).

Éla points out however, that a symbol is accessible only to 'insiders,' it marks the frontiers of a community and separates people into groups (Éla, 2009:35). It is probably because food is symbolic, as Éla and Lupton have said that the politics of food remain unresolved. Since it does not mean the same thing to all people; the approach to address its availability or the lack of it and the motives to aid those who do not have it differ. Let us now look at various symbols of food.

\section{Food as a Symbol of Social Sharing}

In various human societies, sharing food is a symbol of solidarity. It is an eloquent statement of shared ideology as well. Inviting another person to share food with you signifies how close that person is deemed to be. As Lupton ably elaborates: 
The sharing of food is a vital part of kinship and friendship networks in all societies. The extent to which an individual is invited to share food with another individual is a sign of how close a friend or relative that person is deemed to be.... As such, the type of food or meal that is shared and the frequency with which this occurs are strong components of effective ties (1996:37).

Sahlins, as quoted by Lupton (1996:37) points out, "Food dealings are a delicate barometer, a ritual statement as it were, of social relations, and food is thus employed instrumentally as a starting, a sustaining, or a destroying mechanism of sociability. The type of food or a meal that is shared and the frequency with which this occurs are strong components of effective ties, and is therefore directly related to the construction and reproduction of emotional relationships" (Lupton (1996:37).

In many African societies too, food is a symbol of relationships and hospitality. Sharing food expresses human affiliations and solidarity. I remember when we were in seminary, all seminarians that came from Fort-portal and Hoima dioceses referred to themselves as Abalyakamwe, literally meaning those who not only share meals but also share ideologies. As a symbol of African relationships and hospitality food is embodied in the ethics of ubuntu with its virtues of contentment, egalitarianism and sharing. According to ubuntu ethics no one is denied food. No one is alienated when it comes to sharing food. As Bénézet Bujo accounts:

When I was still a child, it often happened that my mother had prepared a warm meal for us. Then there came foreign travellers, who unexpectedly stopped at our place, and we had to be satisfied with cold food, while the warm meal which was meant for us and to which we were eagerly looking forward, was served to the guests (Murove, 2009:395).

The symbolic meaning of food as a sign of social solidarity and sharing lays a strong positive moral obligation on us who are relatively affluent to ease the suffering and promote happiness of the starving people (Frey \& Wellman, [eds.] 2003:240 The virtue of solidarity, which is about valuing our fellow human beings and respecting who they are as individuals, argues that affluent individuals and nations avoid depriving the poor of their resources, protect them from other exploiters, and support those who are already deprived. Both the ethics of care and the virtue of solidarity make modern science and technology irrelevant as long as the situations of inequality, poverty, and injustice continue to exist. It mocks our pieties, makes our call for reviving ubuntu ethics dubious, and questions our commitment to the concepts of human rights, equality and democracy. Our starving brothers and sisters are litmus for any claim we make concerning sustainable development, human rights and human dignity among other things. Unfortunately, there are many people and nations that deny that we have any such obligations.

\section{Food and Social Identity}

Food lies at the heart of everyone's and groups' cultural identity. Social groups throughout time have used diet to differentiate themselves from one another (Wylie 2001:23). Some types of food are associated with high-class as well as low-class people, the rich as well as the poor. It also reflects regional and geographical identities of people. It is a source of pleasure, comfort, and security. It is a social-cultural product. It changes meaning with where we are, and where we come from. Some foods are linked to the age and sex of the individual. There is food for girls, boys, men, women, and elderly as well as expecting mothers. There are foods for weekdays as well as foods for Sundays or special occasions. There are foods for guests and food for ordinary people. 
Each nation has its national dishes or foodstuffs, and in many countries, each region has its cuisine by which it identifies itself or is identified by others. Hence the popular saying that "Tell me what you eat, and I shall tell you what you are" (Wylie, 2001:26). In America for-instance, having a turkey on a thanksgiving day reaffirms their identity as Americans. Likewise the annual International Dinner Festival held by some American communities, is an occasion for people from all continents not only to display their cuisines but also to identify themselves. On such an occasion people identify themselves with what they eat and how they cook it. It is an occasion and function of displaying where one comes from. It is also a day when people feel close to each other; not only with those with whom they share a background but also with others who enjoy their cuisine. Refusing to eat what people from another culture offer is an offense towards them and scorning other people's food is equivalent to attacking their identity. Elaborating on food as a symbol of social identity the British writer, Gilbert Adair indicates that the British symbolically assert their national identity by eating fish and chips - meaning that fish and chips are not only a culinary sign of Britishness but they also signify the popular (rather than gourmet food), the ordinary and everyday, childhood, and one's 'roots' blurring class boundaries (Lupton, 1996:26).

Besides beings a symbol of social and national identity, food also stirs each person's emotions, both because of its sensual properties and its social meanings (Lupton 1996:31). Implicitly, there is a nexus between the physical nature of food and the emotional response it evokes. The actions of preparing it, touching it, smelling it, taking it into the mouth, chewing and swallowing it are all sensual experiences that may evoke particular emotions on both the conscious and unconscious levels (Lupton 1996:31).

There is also a relationship between food and memory. There is no individual for whom at least one specific food - the memory, taste, or smell of it - does not evoke a pang of loving nostalgia. The nostalgia for food became a personal experience during my stay in America. Besides the availability of other types of food, many Ugandans including myself, felt so unsatisfied that whenever we would gather as Ugandans and shared our Ugandan cuisine we felt as if there was a reproduction of our culture in diaspora (Watson and Caldwell, 2005:204). Those cultural gatherings crowned with sharing our traditional meals created for us what Purnima Mankekar points out, that food functions as cultural mnemonic, enabling the production and consumption of particular narratives of the past, a past rooted as it were, in the shifting signifier that is the homeland (Watson and Caldwell, 2005:206). It recalled the images by which we understood who we have been, who we are, and who we should be in the foreign land (Watson and Caldwell , 2005:206).

Sharing our traditional foods awakened our memories and made us feel as if were back in our motherland - Africa. Elaborating on the relationship between food and memory Lupton (1996:32) indicates that food is an element of the material world, which embodies and organises our relationship with the past in socially significant ways.

The effects of memory are inscribed upon the body, in terms of such factors as posture, styles of walking, gesture and appetite for certain foods. The taste, smell and texture of food can therefore serve to trigger memories of previous food events and experiences around food, while memory can serve to delimit food preferences and choices based on experience (Lupton, 1996:32).

As far as food insecurity is concerned, food as a symbol of social identity and memory implies that denying the starving and hungry people an opportunity to feed themselves does not deprive them of material satisfaction only but also of their social identity. Similarly, in the process of assisting the hungry people, donors should seriously consider engaging the hungry people, especially elderly as well as foreigners, so that they avoid the mistake of 
giving them food that will satisfy their physical hunger but leave them nostalgic at the same time. For example, giving the elderly people processed food may leave them with nostalgic feelings of foodstuffs they used to eat, how they were cooked and eaten. Recently a young man from KwaZulu-Natal Province told me that his grandmother would rather starve to death rather than eating pizza. Hence, offering such a person such food would not satisfy that person's hunger.

Likewise, we might mistakenly think that giving immigrants and refugees parcels of food will satisfy their hunger. In most cases this is not true. I came to realise this recently when I shared some few pieces of cassava - the staple food in Rwanda - with a lady from Rwanda who lives in Retreat, Cape Town. When I met her again she narrated how cooking and eating those pieces of cassava not only brought her family together but also made whole family feel as if it were back in Rwanda. Another incident also concerns a lady from Sudan who lives in Cape Town. She told how her family used to order her traditional food - Kasra and Okra - from home until she found a shop that sells the foodstuffs. These examples point out that addressing the problem of food insecurity is more than providing material foodstuffs only. It also requires considering the psychological part of it. This challenges donors especially to be aware that instead of delivering food which might not meet the interests of the hungry and the needy people, it is better to engage them first. From such engagements and dialogue, they will reach consensus. For example, one of the possible solutions could be that the donors buy the required food from the local markets. However much this process may seem to be tedious and expensive, it will end the problem of paternalism and help to give people what they really need. Moreover, the poor and the needy deserve to be treated with dignity. Being poor does not remove their right to make a choice of what they should eat.

\section{Food and Class/Social Differences}

Besides being a symbol of geographical and cultural identities as we have seen, food is also a symbol of class identity and social status. Rich people and persons of the upper class define themselves according to the refinement of their manner and the food they eat. The price of food, its rarity, as well as the place where one eats it make food a boundary marker between the rich and the poor. Such foodstuffs are referred to as a "mark of ostentatious wealth and luxurious living enjoyed by gluttonous ... effeminate and corrupt people" (Beer, 2010:61).

For many of us, eating food in a restaurant is perceived as a sign of civilised living. Yunxiang Yan (Watson and Caldwell, 2005:88) points out that one of the major reasons why fast foods, e.g. McDonald's and Kentucky Fried Chicken (KFC) have taken deep root in Beijing, China is that they symbolise American modernity. According to Yan, "To many Beijing residents, American also means modern, and thus to eat at McDonald's is to experience modernity" (Watson and Caldwell, 2005:88).

Yan's observation is not limited to China only. Even in Africa and South Africa in particular getting food from super markets and buying fast foods correspond to the emergence of a new class of consumer (Watson and Caldwell, 2008:71). Surprisingly, while in Asia and Africa fast foods symbolise high-class people, for many Americans fast foods are taken to be a symbol of poverty as the rich people gobble slow and organic foods.

The perception of equating fast foods with both wealth and modernity throws a big challenge to the field of food ethics and food insecurity. It calls for the decolonisation of minds through liberative education. People need to be conscientised and be aware that although some foodstuffs may taste delicious, it does not necessarily mean that such 
foodstuffs are healthy. Secondly, people need to understand that not everything coming from Europe and America such as education, religion, lifestyle, culture, and food is always superior to what is in Africa. Actually, while many Africans abhor African cuisine, I have met some tourists who enjoy it more than Africans themselves. Addressing the problem of food insecurity demands that we take precautionary measures towards fast foods as well as embracing the increase of food production brought about by modern biotechnology such as 'miracle wheat' and 'miracle rice' and other Genetically Modified Organisms: GMOs (Cummings, 2008:59ff). While the motive embracing modern means of food production may be very good, we should not forget to address the fundamentals. Food can, perhaps be increased: but what about the possibilities of being dangerous tohuman life? The impact of GMOs on the lives of the recipients, the impact of green revolution on domestic agricultural biodiversity should not be ignored (Zerbe: 2004:593-608).

The colonisation of minds, which leads to the detestation of especially traditional food, is common in Africa particularly among the young people. For example, in South Africa many black South Africans abhor fresh milk from locally owned cows. They consider it to be dirty and think it smells bad. In fact, although many people rear cattle in rural areas, they rarely consume milk from them. Instead, they prefer buying milk from supermarkets, which are largely owned by the white business people. Surprisingly enough, when white farmers drive through villages selling fresh milk or sour milk, black people buy it because a white man is selling it.

I witnessed this bizarre behaviour while I was still working in the Eastern Cape Province. The youths from St. Anthony parish, Lusikisiki, in Kokstad diocese visited Taylorville Parish. On the day of their arrival, they had no problem drinking tea/coffee with milk - from the parish cows - that was served. The youths did not know that the milk was from the local cows. Apparently it tasted normal. They thought that it had come from supermarkets. The following day however, they refused to take it on account of having seen the cows being milked. Previously they had not known that the milk they took was directly from local cows.

The paradox of having different tastes for the same food because different peoples produce it reflects the colonisation of the mind which apartheid implanted. It corrupted black peoples' minds not only to hate what is African but worse, to mistrust and fear each other. Their minds are corrupted so much that they associate the quality of food with race. Good and plentiful food is associated with a white person who is seen as the ideal person or demigod. On the other hand, bad quality food is associated with a black people who are considered as less human.

Instead of feeding the children with mealie-mealie porridge [porridge made out of corn] or sour milk which is organic and nutritious, some parents want to feed them with watery sifted maize meal gruel or even Coca-Cola or juice from shops, because they consider that to be a sign of advanced culture (Wylie 2001:188). Actually, it is common to hear someone saying "Today I/we have eaten like white people" meaning that the meal was exceptionally good and consisted mainly of processed foods. Many black people loathe eating fresh vegetables like pumpkin leaves freshly picked from their gardens [although they would buy those vegetables if a white person was selling them], but they gobble processed food like American style Kentucky Fried Chicken because they consider it food for the high class people, i.e. the white people.

Although people grow maize, they still buy mealie-mealie (maize flour) because the traditional home ground mealie-mealie is no longer made. All these are indications that food symbolises the class and social status of people. The apartheid of mind made black 
people look at themselves and their foods as inferior and unhealthy. Some people are likely to starve while there is plenty of food around them. For example, when the food is not fried or when it is a traditional food cooked traditionally by a local person in traditional pots, such food will come second to the processed one, served by a white person in modern cooking pots.

\section{Food and Social Discrimination}

Besides being a symbol of acceptability, social identity, and hospitality food can also be a symbol of denigration. In almost all cultures, diet is one of the characteristics distinguishing the deserving from the undeserving poor. As high-class people are admired and imitated for what they eat as we have seen, the poor are sometimes scorned and belittled due to the type of foods they eat. Beer (2010:19) points out that while Barley served as staple food was perfectly acceptable among the ancient Greeks, the Romans considered it inferior, suitable only for use as animal fodder or food given as a punishment for insubordination amongst the ranks of the Roman army. Likewise, Gandhi narrates the feelings he had after eating meat:

... The goat's meat was a tough as leather. I simply could not eat it. I was sick and had to leave off eating. I had a very bad night afterwards. A horrible nightmare haunted me. Every night I dropped off to sleep it would seem as though a wild goat were bleating inside me, and I would jump up full of remorse... If my mother and father came to know of my having become a meat-eater, they would be deeply shocked. This knowledge was gnawing at my heart (Fiddes 1991:67).

In Africa too, some foodstuffs are considered unfit and people who eat them are scorned. In some communities wild food such as tubers, bulbs and fruits are thought of as negligible and a sign of poverty reserved for the poor and the undeserving. In some parts of Africa, eating pork, snakes, monkey, fish, and insects like grasshoppers among others is abhorred. The Rwandese loathe mutton for it is considered to be unfit for a true Rwandese and only fit for the minority and marginalised Batwa. Likewise eating mealie-mealie commonly known as posho in some parts of Uganda is considered as a sign of poverty or punishment. It is supposed to be food for prisoners. The implication of food as a symbol of social discrimination is that some people can choose to starve rather than eating such food. Eating it would be tantamount to self-abasement or being disloyal to one's cultural/religious belief as Gandhi has said and as some Jews did during the time of Maccabees (2 Maccabees 6:18-31).

\section{Food as a Symbol of Health/ill-health}

Throughout history, people from different cultures have recognised the relationship between food and health. Farquhar (2002:49) reports that Chinese cookbooks and the new genre of books on herbal cuisine emphasise their medicinal value and the importance of nutritional therapies dating from earliest times. While some types of foodstuffs are considered deadly, others are desired because they are considered to be healthy and a solution to problems including old age, illness, and cosmetic aspects such as wrinkling of the skin and expanding girth (Lupton 1996:137). Some foodstuffs are represented as pathogens, a source of diseases and ill-health. A number of medical conditions and non-communicable diseases such as diabetes, kidney diseases, hypertension, obesity, and some forms of cancer are linked to food habits (Slocum and Saldanha, 2013:272). Similarly, some behavioural 'disorders' or 'anti-social' behaviour such as hyperactivity and juvenile delinquency have 
been linked to the consumption of junk food by children (Lupton 1996:75). I believe that there is some level of truth in relating food to health. We are what we eat. Some people in Uganda even believe that eating fish does not only lead to bodily health but also it leads to intelligence.

Nevertheless, the relationship between food and health is complex. Besides being a necessary condition for survival in our daily lives, food also has wide-ranging implications for our health and well-being. It can support good health and enhance health potential, and yet it can also be a key factor influencing ill-health. Amazingly, some people think that mere consumption of the desired food would lead them to literally partake of its essence such as, a healthy body, which in turn is attractive, youthful and sexual. It is alleged that even Gandhi thought that consuming meat would gain him the physical strength he badly desired to fight the imperialists. "It began to grow in me that meat-eating was good, that it would make me strong and daring, and that, if the whole country took to meat-eating, the English could be overcome" (Fiddes 1991:67). Many people largely assume like Gandhi that healthy food equals healthy body as much as poor food leads to poor health.

The relationship between food and health implies two major points. Firstly, the people who are keen on health issues are likely to choose going hungry/abstaining rather than eating the type of food which they considered dangerous to their heath. For example, people who are pursuing idealised body weight or shape are likely to abstain from such food like red meat or fast foods among others. Secondly, food security means much more than the availability of any types of foodstuff. It means both quality and quantity. Consequently, although some people might seem to have enough food to fill their stomachs they might still be food insecure. This is common in rural areas where people lack a balanced diet. For example, according to Health System Trust (14 November 2011) in South Africa 35\% of high school girls are found to be overweight or obese while one in every five children under nine is stunted due to malnutrition. According to the report, stunted children were not necessarily going hungry, but were rather receiving food that did not contain the nutrients essential for growth at this critical age. In this regard addressing the issue of food insecurity must consider the quality and quantity of food as well.

\section{Food as a Symbol of Power}

Looking at food as a symbol of power and a way of controlling the weak is one of the reasons that have perpetuated food insecurity in the whole world. Slocum and Saldanhan (2013:74) indicate that the right to a meal has been used in specific historical periods to deny some people their fundamental humanity. According to these scholars, food deprivation underscores each person's demotion from human being to commodity, the loss of social status and cultural identity, of being made a kinless and orphaned prisoner. These scholars further highlight that during the time of the slave trade, slaves were served monotonous bland porridges and gruels as a way of alienating them from their world.

Unfortunately, even today food still serves as a symbol of power and a means of controlling the weak right from the family up to the international level (Moore Lappé et al., 1998:4). Globally, rich nations use food as means and weapon to achieve their political ends. In her book, How the Other Half Dies: Reasons for World Hunger Susan George shows how some of the officials in the USA government referred to food as a weapon to fight and control their enemies.

Officials sometimes concede a great deal. Earl Butz was widely quoted as saying, "Food is a weapon. It is now one of the principle tools in our negotiating kit." He was backed by no less a personage than ex-President Ford, who made headlines in September 1974 by 
announcing from the rostrum of the United Nations that OPEC countries had better watch their step, or the US would have to use food as a weapon, as he claimed they were using oil (1982:179-180).

Using food as a weapon is a common practice not only among the rich nations. In Africa too, some politicians use food to solicit votes during elections campaigns. Some individuals also use food as weapon of exploiting and abusing others. It happens so often that rich men and women known as 'sugar daddies/mammies' or 'blessers' use food to trap and exploit young girls and boys for sexual purposes.

In families too, food is used as symbols of power. In many African families there is imbalance of sharing food based on gender. As Walker Bynum (2008:129) elaborates, from medieval times, food has always been a symbol of controlling women. Women were associated with food preparation and distribution rather than food consumption. "They were sometimes relegated to watching from the balconies while gorgeous foods were rolled out to please the eyes as well as the palates of men" (Counihan and Van Esterik, 2008:129). Fiddes agrees that gender inequality in sharing food is institutionalised in many ways and around the globe. Men have long been allocated an unequal proportion of available food, particularly meat. Also Kerr and Charles indicate that:

Women, on whose shoulders fell the responsibility for managing the limited household budget and for ensuring that the family was adequately fed, frequently did without food themselves in order that their husbands and children were less likely to go short. Men's food needs were often privileged because of the necessity of keeping them fit for wage work (Fiddes 1991:158).

In many African communities food is not shared equally between males and females due to some patriarchal attitudes and structures that endorse and perpetuate male dominance. Despite their major roles, women still face different forms of injustice and discrimination (Jong, 1993:103). Women are income earners, food producers, food preparers and child carers. They are also heavily involved in ensuring household food security and adequate child nutrition (Walsh 1998:23-24). ${ }^{3}$ Women are principally responsible for tasks such as collection of water, fuel wood, preparing and serving food, rearing children, and family health care. The role played by women in the livelihood of everybody in society is summarised by feminist ethicist Jong who points out that "The world would be a much worse place tomorrow than it is today were women suddenly to stop meeting the physical and psychological needs of those who depend on them (1993:103).

South African women suffer twice: they suffer together with men from the legacy of past discriminatory laws and practices which is a major cause of food insecurity, but they also suffer from their unequal position in public affairs as well as in family and social life. It is widely accepted that in rural South Africa more than half of rural households are headed by women together with children who make up the poorest of the poor. Edith Dlamini puts it succinctly that "South African women are slaves of slaves" (Gibellini, 1994:166). Addressing the problem of food insecurity demands that we address the problem of power imbalance and the marginalisation of women who are the main victims of food insecurity.

3 Martha Walsh, "Time for Change: Food Aid and Development. Women in Food Aid Interventions: Impacts and Issues, ” Institute of Development Studies, University of Sussex, UK (October 23-24, 1998). 


\section{Food and Sex}

It is arguably believed that there is a close relationship between eating and sex. For example, Fieldhouse as quoted by Fiddes (191:144) reports that traditionally, hunger is seen as a basic drive for survival of the individual whilst sex is a basic drive for survival of the species. Besides looking at both sex and eating as driving forces for survival, scholars further show that both sex and food are largely products of social and cultural processes.

The relationship between food and sex is heightened, as some foods are associated with women while others are men related. As Lupton points out:

It is not only socio-economic privilege and relative possession of cultural capital that shape food preferences. There is clearly a gendered division in contemporary western societies, incorporating a number of assumptions concerning the types of food men prefer and those women prefer (1996:104).

Lupton goes ahead to show that "One dominant association is the linking of sweet foods with women while men are typically associated with red meat” (1996:104).

Associating food with gender implies two major things. Firstly, it positively implies that the gender to which the food is associated has a prerogative of it. For instance, in African settings men seem to have a right over meat. The reason is it is assumed that meat gives men more strength (especially sexual strength). That is, meat is widely reputed to inflame the lustful passion in men. As Fiddes highlights, "Meat is almost ubiquitously put to use as a medium through which men express their natural control of women" (1996:146). According to this perception, "a beefsteak can send powerful sexual signals. The larger and juicier the piece of meat, the more red-blooded and virile the consumer is supposed to be, and a steak by candlelight is a common prelude to seduction..." (Fiddes 1996:146). It is reported that the captain of a slave ship in the throes of evangelical conversion, stopped eating meat to prevent his lusting after female slaves. Likewise nineteenth and even twentieth century educationalists recommended a low meat diet for male adolescents to discourage masturbation. It is probably owing to this perception that some men not only see themselves as having a prerogative over meat but also tend to have a passion for meat, as they are obsessed about women. They look at women as sexual objects that must satisfy their sexual desires as the steak of meat satisfies their appetite for food.

While meat is considered masculine and fit for men, fish is considered as unfit because it is 'feminine.' Bourdieu indicates that among the French working class fish is considered an inappropriate food for men because it is light, insubstantial and 'fiddly' to eat:

Fish has to be eaten in a way which totally contradicts the masculine way of eating, that is, with restraint, in small mouthfuls, chewed gently, with the front of the mouth, on the tips of the teeth (because of the bones). The whole masculine identity - what is called virility - is involved in these two ways of eating, nibbling and picking, as befits a woman, or with whole-hearted male gulps and mouthfuls (Lupton 1996:104).

Equally too, as French men abhor fish, a male vegetarian can be a suspect figure. Fiddes (1996:147) reports about a vegetarian male student who recalls of his period living in a new community: "It was really odd; they seemed to automatically assume that because I was vegetarian then I must be gay. I'm sure it was because of the thing about meat being a sort of virility symbol."

The second negative implication of equating food with gender is that sometimes the gender to which the food is associated might not be allowed to eat that type of food, because eating that type of food is tantamount to self-destruction. For example, in some parts of Uganda women do not eat lungfish apparently because it has breasts. In some parts 
of Africa women are not allowed to eat antelope or crocodile meat for fear that they will be jumpy and aggressive respectively. Equating food with sexual virility is not limited to meat only. In some parts of Easter Cape young girls are not allowed to eat eggs, avocado, peanuts and fresh milk for fear that they would become sexually active at an early age. Likewise, traditionally Xhosa men were not allowed to eat vegetables besides cabbages and spinach for fear that they would become sexually weak.

\section{Religious Significance of Food}

While some foodstuffs are disliked because of peoples' attitudes towards them as being inferior, as we have already seen, other foods are taboos because of religious symbolism attached to them. Eating such foods would be considered as impure, polluting or spiritually corrupting. In many societies diet and dietary restrictions are often used as a metaphor for purity or virtue. In ancient Greece, fish and beans were prohibited due to religious symbolism. Plato identified the eating of fish with profligacy and weakness, hence an aberration from the austere diet of an earlier epoch where devout men and women were not expected to live a luxurious life (Beer, 2010:48, 62).

Even in South Africa, some foods associated with wanton behaviour are prohibited from initiates into religious life undergoing purification functions. For example, recently I had a conversation with a nurse who works in one of the hospitals in KwaZulu-Natal, South Africa. She narrated a case of a nine-year-old girl who was brought to the hospital, chronically ill and almost dying from different kinds of diseases. After a thorough examination, it was discovered that the girl was suffering from recurring hunger. Surprisingly, the medical team discovered that the cause of hunger was not the lack of food at the girl's home but the fact that she was not allowed to eat some kinds of nutritious foods because she was being initiated to become a spiritual medium commonly known as a sangoma.

According to Beer, some of the reasons why some foods are religiously prohibited are that; firstly, it is a technique that seeks to facilitate the achievement of a state of purity for the initiate. Secondly, such a prohibition is an allegorical message, a code designed to prevent other forms of behaviour and, thirdly, such foods are perceived to be a source of potential psychological and psychic disturbances (Beer, 2010; 48). Besides those that are prohibited, there are other foods, which are reserved and eaten only on special occasions for religious purposes. For example, in some areas of Eastern Cape a goat is slaughtered on special functions such as when a new member of the family is being introduced to the ancestors. It must be plain white, slaughtered and cooked in the kraal by men, surprisingly. It is served with plain samp and boys are the only ones who are supposed to eat the neck. ${ }^{4}$

In the wakes of this disturbing situation of food insecurity perpetuated by cultural and religious symbolisms, religious communities have a paramount but also a challenging role to play to change peoples' mind-set. As John Mary Waliggo, reports:

Genuine religion should be liberating, transforming and empowering to individuals and communities in order to realise their God-given potential. It should also promote the protection life and enhancement of the values of love, justice, peace, integrity and the preferential care for the poor and the vulnerable (Mwaura, 2008:74).

The following section will focus on the Eucharist, which in its various symbols can become a source of both the motivation and sense of direction to the faith-based communities in

4 This information was given to me by Mr Nkosinathi Skade, a lecturer in the Faculty of Arts at the University of the Western Cape in the discussion we had on August 5, 2015. 
preaching the gospel message of God's Kingdom where nobody lacks anything especially food.

\section{The Relevance of the Eucharist to the Eradication of Food Insecurity}

The Eucharist, which holds a central place in Christian communities, means 'thanksgiving'. It is an act of giving thanks to God for sharing Jesus Christ with the world (Gutiérrez, 2006:134). It is primarily a proclamation of the love Christ to the world manifested by his death and resurrection. It is also a meal that anticipates and celebrates the banquet of the Kingdom. Whenever the Eucharist is celebrated, the Reign of God is anticipated (Boff, 1984:92). It is the heart of the Gospel. Like those who first ate and drank at the table of the Lord, whenever Christians gather today at the table, they have no choice but to proclaim the Gospel to all (Bevans \& Schroeder, 2006:263). It nourishes the spirituality of the believers and strengthens their commitment to give of themselves and their resources to all people of the world, especially the poor. The act of thanksgiving that is the Eucharist, expresses confidence that the communion of life that does not yet exist among believers will become a reality. This anticipation is not an evasion, but a motivation to a present commitment. Whenever the Eucharist is celebrated especially among the poor and the oppressed, it becomes both a promise and demand for justice, for the freedom and the fellowship for which the people struggle (Gutiérrez, 2006:134). Three inner sources stand at the heart of the Eucharist: faith, prayer and the Holy Spirit.

\section{Faith}

The Eucharist is exemplified by the summit of New Testament faith. The Christians' gathering together at the Eucharist is obedience to Jesus' command, and this obedience is called faith. The Christians assemble not to socialise or enjoy entertainment, but because they believe that Jesus is risen, is still with them, still speaking to them; "this is my blood". The celebrating community is presented with the demand to follow Jesus Christ. Following Christ implies accepting to be broken for the sake of others as Jesus was. Not only must believers have faith but they must also cooperate actively in preaching the kingdom and turning it into a full reality (Sobrino, 1979:57). To live the faith means to put into practice, in the light of the demands of the reign of God, the fundamentals of Christian existence.

The bread and cup that Christians share as the Eucharistic celebration do not only symbolise but also effect true oneness. The Eucharist makes believers one body in Christ (Grassi, 2004:66). As St. Paul recounts "All of you who have been baptised into Christ have clothed yourselves with him. There does not exist among you Jews or Greeks, slaves or freemen, male or female. All are one in Christ Jesus" (Gal. 3:27-28). The moral implication of Christian unity is that believers must share their joys and sorrows with one another. Because they are one in Christ, they must reflect in action and behaviour the equality demanded by the Eucharist. Sharing the bread and cup of the covenant is an outward sign of their commitment to the same justice that motivated Christ (Grassi, 4004a:67). Failure to live according to this virtue is tantamount to breaching the covenantal relationship.

Because of the interrelationship between faith and action, the individuals and the Christian community that worship God must proclaim the kingdom of God-kingdom of love-by sharing with one another whatever they have. St Paul challenged the Christian community of Corinth for failing to observe this relationship: "When you assemble it is not to eat the Lord's Supper, for everyone is in haste to eat his own supper. One person is 
hungry while another gets drunk.... Would you show contempt for the Church of God and embarrass those who have nothing?" (1 Cor. 11:20-22). The challenging message of St. Paul to the rich people of the Christian community at Corinth is still relevant to the affluent Christian communities not only globally but also in South Africa. Those of us who are well to do, ought to end our selfish behaviour by sharing with the hungry. As St James reminds us, a faith that lacks action is death (James 2:26). This means that as the Eucharist is a visible sign of the soteriological actions of Jesus Christ, believers who participate in the Eucharist must bless themselves for action. They must wash the each other's feet as Jesus commanded at the Last Supper. "If I, then, your Lord and Master, have washed your feet, you also must wash one another's feet. I have just given you an example that as I have done, you also may do" (John 13:14-26).

Monica Hellwig emphasises the relationship between the Eucharist and action. "The Eucharist is the assembling of the people for an action. This action is supposed to make a difference, to bring about a change. As faith enabled the sick to be cured and sinners to be released from their sins, it is so with the people of faith who share the Eucharist. It is lived in the church and geared to the communication of the Lord's message. It releases within the people the power that is beyond them to work for the coming of God's kingdom where everyone lacks nothing." What Hellwig says is that the change does not take place in the lives of the believers only but also through the Eucharist the believers bring change to the world. Leonardo Boff puts more vividly as he points our:

The Eucharist cannot be celebrated in the spirit of Jesus wen that celebration is unaccompanied by a hunger for justice. We betray the Eucharist, the memorial of the Lord, when we utilise it for the concealment of, or even when we merely ignore, the presence of unjust relations in the community of the faithful who celebrate and assist at that Eucharist (1984:95).

\section{Prayer}

The lived faith finds expression in prayers, which comprise the second aspect of the Eucharist. Christians gather to pray for the coming of the kingdom of God in their lives and in their society (Grassi, 2004:71). "Prayer is something between the praying community and God; it is praise and adoration of God; it is asking forgiveness for the corporate and personal failing and sin; it is about asking God to be present with the hungry and in the events of the world in which we live" (Bevans \& Schroeder, 2006:261). According to Bevans and Schroeder:

The church is most the church when it is assembled for worship; the Christian is most a Christian when he or she is in attentive dialogue with God; prayer and liturgy are the center of Christian life, and yet that center will only hold if Christian eyes are not on the center but on its periphery (2006:262).

Prayer is the summit toward which the activity of the church is directed; at the same time it the fountain from which all the church's power flows. The moral implication of this is that without participating in the broken lives of the hungry, the prayers of the faith-based communities are incomplete; the efficiency to fulfil this obligation comes through prayers.

Prayer is missionary. Through prayer God acts to empower the church for mission. As Huffman puts it, "Worship becomes a 'ritual rehearsal' for ministry" (Bevans \& Schroeder, 2006:262). Prayer has a social dimension. For example, in the Lord's Prayer, which is the central prayer for Christian worship, the needs and concerns of each individual and of the entire society are united (Grassi, 2004:72). Prayer ought to lead to spiritual conversion so 
much so that Christians are able to share not only spiritual values but also material needs such as food, clothing and other necessities of life. Without disregarding the importance of private prayers, the prayer of the whole community is more efficacious because it unites the prayers to the risen Christ with the believers. In other words, prayer and Eucharist unite Christ and believers in their struggle for the establishment of God's kingdom of justice (Grassi, 2004:72).

In order to enjoy a communion with Christ through prayer, believers must enter into a communion with their brothers and sisters. Of course, this implies a communality of goods, lest anyone suffers need (Boff, 1984:96). Like the first Christian community narrated in the Acts of the Apostles, prayers and the breaking of bread went hand in hand with a communion of goods and union of hearts.

\section{The Holy Spirit}

The third inner source of the Eucharist is the Holy Spirit. The Dogmatic Constitution on the Church in Modern World No. 4 states that in order that the historical deed of Jesus might have perpetual meaning Christ sent the Holy Spirit to carry out the saving work and form a group of followers into a community-in-mission that would mirror the community of overflowing Trinitarian life. The document further points out that the role of the Holy Spirit is to unite the church/community in fellowship and in service; to furnish that community with various gifts. The Holy Spirit vivifies ecclesiastical institutions and instils into the heart of the faithful the same missionary spirit which motivated Christ himself.

The implication of the presence of the Holy Spirit in the faith-based community is that the Spirit enables the believers to get a sense of belonging, and to develop a strong feeling of loyalty and solidarity. The work of the Holy Spirit to unite the church goes beyond members of the same group to the entire human family. As Jesus Christ reached out beyond his own social, cultural, and religious group to embrace the whole of the human race, making all people his brothers and sisters, those who live according to the Spirit transcend the limitations of various social groupings that categorise and define them. Nolan puts it ably:

[t]his basic loyalty to the human race makes me a Christian, a follower of Jesus Christ who identified himself with all human beings: "Whatever you do to the least of my brothers and sisters you do to me." To discover Christ or God in another human being is to transcend all the other things I might have in common with that person and to experience very simply and profoundly the humanity we have in common. This is Christian love, this is divine compassion, this is what moved the Samaritan in the parable to do what he did for a socially despised Jew. We are all brothers and sisters, and God is our Father (2010:109).

Those who live and walk according to the Holy Spirit share the prophetic life. According to Nolan, "The word prophet has three interrelated meanings: those who speak out, those who speak before, and those who speak for. Prophets speak out because they are boldly critical of their world; they speak before because they foresee the future; they speak for because they speak for God as God's messengers" (2010:89).

This means that through the Eucharist, believers are empowered by God's Spirit to become fearless and confident so that they are able to speak out boldly and powerfully regardless of the consequences (Nolan, 2010:89). They speak against all forms of injustice, against religious assumptions and accepted norms that sometimes lead to the suffering of the poor. Their message is time-bound in the sense that it arises out of the signs of a particular time and situation, for example food insecurity and is addressed to particular 
people - who perpetuate injustice and inequality - who live in that time and that place (Nolan, 2010:90).

The Spirit of God enables the believers to feel for the hungry with God. Because of the Spirit, they are able to share God's attitudes, values and emotions which enable them to see the events of injustice, inequality and food insecurity as God sees them and to feel the same way about these events as God feels them (Nolan, 2010:95). Through the Holy Spirit, the Church is commissioned to help safeguard and promote a humane and just life to all people. As St. John Paul II put it "The Church... has the duty to proclaim the liberation of human beings, among whom are many of the Church's own children; the duty to help bring this liberation forth in the world, to bear witness to it and make sure that it is total" (Evangelii Nuntiandi, No. 30).

\section{Conclusion}

Food is built into cultural practices and materials referred to by sociologist as foodways (Macionis and Plummer, 2008:224). That is, attitudes, values and beliefs collectively referred to as culture play an unquestionable role in human behaviour and in giving meaning to food. Besides preserving the status quo common to many African cultures, food symbols are a psychological refuge in which peoples' ignorance finds its answers and their wildest fantasies become realties (Harrison and Huntington, 2000:73). A society in which food symbolism flourishes cannot avoid being sensitive to food insecurity. Consequently, if the problem of food insecurity is to be eradicated and the right to food becomes more than simply pious words, the state, religious communities and individuals need to work together to address the cultural and religious codes and norms that play a major role in shaping people's minds to determine what they must eat. The purpose might not be to do away with these symbols completely but to scrutinise them and make them match the signs of the time.

The obligation of ensuring that each person is food secure calls on the state, communities and their leaders, not only to create essential structures that can address the issue of poverty, food production and distribution, but it also calls for social cohesion at the level of community and its inhabitants as well as the level of individuals and the clans to tackle rules, regulations and symbols, which lead to food insecurity. Religious communities in particular must remember that genuine religion is liberating, transforming and empowering to individuals and communities in order to realise God-given dignity. Both religious and civil society must work together to create conducive ethical environment in which every citizen subscribes to the principle that food is a basic human right - as it is stated in the South African constitution and the Bill of Rights - which must be enjoyed by everyone, and that this basic human rights must be respected, defended against being destroyed by third parties and provide for the people deprived of it (Brand and Russell, 2002:71-72). As Boff (1984:60), writes, the right to food is fundamental because it constitutes the right to life, which is sacred and inalienable. Thus it takes precedence over any other right. "The right to life is an infrastructural right: upon its foundation all others will be erected."

Because God is the God of life, and the guarantor of the fundamental rights of the poor, to believe in God is to believe in the life of all, especially the poor. Belief in God is incompatible with the death of hungry people. Where life is oppressed, God is oppressed. Where religion does not help to expand life, animate life, we must wonder what god is being preached and worshipped (Boff, 1984:62). The task of believers is to accept the mission of the Jesus Christ, the one who "brings good news to the poor, proclaims liberty to captives, and frees the oppressed" (Luke 4:18). Therefore, whenever the religious com- 
munities celebrate the Eucharist, they must do what Jesus Christ did when Jesus said "Do this as a remembrance of me": they must let themselves be broken for the sake of others, they must be willing to die to themselves, and to share themselves in thanksgiving to God as the indispensable condition for becoming the body of Christ (Éla, 2005:1). The Eucharistic celebration becomes relevant only if the celebrating community shares in the ministry of Christ in the Spirit by reaching out to the hungry brothers and sisters.

\section{BIBLIOGRAPHY}

Beer, Michael 2010. Taste or Taboo: Dietary Choices in Antiquity. Great Britain: Prospect Books.

Boff, Leonardo 1984. When Theology Listens to the Poor. San Francisco: Harper and Row Publishers.

Brand, Danie \& Ruyssel, Sage, (eds.) 2002. Exploring the Core Content of Socio-economic Rights: South African and International Perspectives. Pretoria: Protea Book House.

Counihan, Carole \& Penny van Esterik 2008. Food and Culture, $2^{\text {nd }}$ ed. New York: Routledge Publication.

Crush, Jonathan, Miriam Grant \& Bruce Frayne 2007. Linking Migration, HIV/AIDS and Urban Food Security in Southern and Eastern Africa. Cape Town: Idasa.

Cummings, Claire Hope 2008. Uncertain Peril: Genetic Engineering and the Future of Seeds. Boston: Beacon Press.

Drèze, Jean \& Amartya 1989. Sen. Hunger and Public Action. Cape Town: Oxford University Press.

Éla, Jean-Marc 2009. My Faith as an African. Eugene, Oregon: Wipf and Stock Publishers. Éla, Jean-Marc 2005. African Cry. Eugene, Oregon: Wipf and Stock Publishers.

Farquhar, Judith, (ed.) 2002. Appetites, Food and Sex in Post-socialist China. Durham: Duke University Press.

Fiddes, Nick 1991. Meat: A Natural Symbol. New York: Routledge.

Frey, RG \& Christopher Heath Wellman 2008. A Companion to Applied Ethics.

Massachusetts, USA: Blackwell Publishers.

Friedland, R Susan (ed.) 2008. Food and Morality. Great Britain: Prospect Books.

Gassi, Joseph 2004. Broken Bread and Broken Bodies. Maryknoll-New York: Orbis Books. Gibellini, Rosino 1994. Paths of African Theology. Maryknoll, New York: Orbis Books.

Goldewijk, K Berma \& Bas de Gaay Fortman 1999. Where Needs Meet Rights: Economic, Social and Cultural Rights in a New Perspective. Geneva: WCC Publications.

Hellwig, Monika K 1992. The Eucharist and the Hunger of the World. Sheed and Ward, London.

Jong, Rosemarie 1993. Feminine and Feminist Ethics. Belmont, California: Wadsworth Publishing Company.

Lupton, Deborah 1996. Food, the Body, and the Self. London: SAGE Publications.

Macionis, J John \& Ken Plummer 2008. Sociology: A Global Introduction $4^{\text {th }}$ ed. Cape Town: Pearson Prentice Hall.

Marsh, Charles \& John Perkins 2009. Welcoming Justice: God's Movement toward Beloved Community. Illinois: IVP Books. 
Marx, L Herbert (ed.) 1975. The World Food Crisis. New York: The HW Wilson Company.

Moore, Lappé Frances and Joseph Collins, Peter Rosset \& Luise Esparza 1998. World Hunger: Twelve Myths, $2^{\text {nd }}$ edition. New York: Groove Press.

Murove, F Munyaradzi (ed.) 2009. African Ethics: An Anthology of Comparative and Applied Ethics. Scottsville, South Africa: University of KwaZulu-Natal Press.

Nelson, A Jack 1980. Hunger for Justice: The Politics of Food and Faith. Maryknoll, New York: Orbis Books.

Nolan, Albert 2010. Hope in an Age of Despair. New York: Orbis Books.

Pope Paul VI 1975. Evangelii Nuntiandi-Evangelization in the Modern World. Rome.

Sachs, Jeffrey D 2005. The End of Poverty: Economic Possibilities for Our Time. New York: The Penguin Press.

Sen, Amartya 2000. Development as Freedom. New York: Anchor Books.

Simon, Arthur 1975. Bread for the World. New York: Paulist Press.

Slocum, Rachel \& Arun, Saldanha (eds.) 2013. Geographies of Race and Food: Fields, Bodies, Markets. USA: Ashgate Publishing Company.

Toton, Suzanne C 1982. World Hunger: The Responsibility of Christian Education.

Maryknoll, New York: Orbis Books.

Velasquez, Manuel G 2006. Business Ethics: Concepts and Cases $6^{\text {th }}$ edition. Upper Saddle River, New Jersey: Pearson Prentice Hall.

Vermeer, Adri \& Hugo Tempelman (eds.) 2008. Health Care in Rural South Africa. Amsterdam: VU University Press.

Watson, L James \& Melissa L Caldwell 2005. The Cultural Politics of Food and Eating. Malden, USA: Blackwell Publishers.

Wylie, Diana 2001. Starving on a Full Stomach. Charlottesville and London: University Press of Virginia.

\section{Secondary Sources}

Awetori Yaro, Joseph 2004. "Theorising Food Insecurity: Building a Livelihood Vulnerability Framework for Researching Food Insecurity," Norwegian Journal of Geography, Vol. 58, No. 1:23-37.

Urmilla, Bob 2011. "Rural African Women, Food(in) Security and Agricultural Production in the Ekuthuleni Land Redistribution Project, KwaZulu-Natal." "JSTOR: Agenda, No. 51 2002:16-32. Available from http:www.jstor.org/pss.; Internet; accessed on July 21, 2011. 